\title{
The Walking Dead: the Anthropocene as a ruined Earth
}

Dr Nicholas Beuret (corresponding author)

Lancaster Environment Centre, Lancaster University

Email: n.beuret@lancaster.ac.uk

Phone: 07742947921

Lancaster Environment Centre, Lancaster University

Lancaster, UK, LA1 4YQ

Dr Gareth Brown

School of Business, University of Leicester

Email: gsb23@leicester.ac.uk

Phone: 07910887324

School of Business, Ken Edwards Building, University of Leicester

University Road, Leicester, LE1 7RH UK

\begin{abstract}
Much has been made of the claim that humanity has ascended to the status of a terrestrial force and inaugurated a new geological epoch, the Anthropocene. While attention has been paid to the contestable nature of the epoch and its disputed histories, insufficient attention has been paid to the significance of the Anthropocene for political praxis. Contrary to much Anthropocenic discourse that articulates a renewed sense of mastery over nature through assertions of humanity's complete subsumption of the environment, recent work in both science and technology studies and human geography suggests an alternate reading of the Anthropocene as an epoch without mastery, one where humanity exists in a permanent state of vulnerability. The political significance of this state of vulnerability is explored through a reading of popular TV show The Walking Dead, a post-collapse narrative of a world in ruins and overrun by zombies. On a ruined earth, political praxis is orientated not towards a return of the earth to its previous productive state, but rather as an unending labour of survival and salvage. Survival is not a life reduced to bare life, but rather a state of tension between a life reduced to necessity, and the refusal to separate the question of how to live from the work of securing life itself. Left unresolved, this tension animates the politics of the Anthropocene, suggesting that in place of the teleology of progress social life is organised within it through unceasing care and repair time.
\end{abstract}

Key words: Anthropocene, survival, salvage, ruination, bare life, Agamben 


\section{1 - Introduction ${ }^{i}$}

Island nations are subject to the slow violence of rising seas. Drought and savage weather events drive cycles of migration and violence. Storms and heat waves batter Europe and North America. Slowly tales of the Anthropocene as an unending series of disasters gather pace (Waters et al. 2016). What is articulated in the idea of the Anthropocene is not a speculative future disaster (Adams, Murphy and Clarke 2009) but a past event. Unlike other 'images of doom' (Buell 1995), the Anthropocene names something that has already happened that 'humanity' must now adapt to rather than a future disaster that must be prevented. The Anthropocene, considered as a breakdown in the functioning of the Holocene (Star 1999; Winner 1986), marks a moment where maintenance and repair as practices are transformed from a labour of possible restoration (Jackson 2014) to a ceaseless labour of salvage. The Holocene has ended and cannot be restored. The biosphere is caught up in a long thaw that will reshape the context of life for the next 10,000 years (Archer 2009). There is no return to Modernity, either as an epoch, environment, or project.

How can we practice politics in the Anthropocene, a space of not only of an environmental breakdown but a 'late industrial' (Fortun 2014) ecosystemic state of ongoing disaster (Clark 2014)? The uncertainty of the earth sciences and the urgency of ecological issues such as climate change compel us to reconsider what should count as a suitable object of research or political concern (Latour 2015). Indeed this is perhaps the very point of the concept of the Anthropocene - to compel a planetary mode of politics adequate to issues such as climate change (Steffen et al. 2011). The Anthropocene as a concept has brought to light 'material conditions that not only defy prediction, but reveal the precarious existence of those beings who are asking questions of it' (Clark 2010:21), putting not only the process of research but the researchers themselves into question.

Since the concept of the Anthropocene was first proposed in 2000 it has been significantly developed and informally adopted by geologists and a broad range of scholars and has sparked much debate as to its import and significance (Castree 2014a; Latour 2015; Malm and Hornborg 2014; Szerszynski 2012). It also signals a transformation of these various fields of study, with boundaries between disciplines blurring if not collapsing in many instances. We therefore deliberately move away from the realm of stable truths in this article and into what may at first glance look like the opposite, the realm of speculative fiction.

A small band of survivors find an abandoned prison. They repair the fences, and set to work tilling the fields, building communal kitchens and living quarters. They organise bands to go out looking for food and things to salvage and bring back, as well as find more survivors. Another band of survivors find them, lay siege to their fortified home, the result being the destruction of them all.

The scene above is taken from the TV program The Walking Dead. Based on the comic book series of the same name by Robert Kirkman, it centres on (former) deputy sheriff Rick Grimes who wakes from a coma to find the world overrun with zombiesii and in a state of total social collapse. The narrative of the show stutters and jumps: there is no singular narrative progression from one event to another, with a clear end or terminus. What we see is the emergence then collapse (both partial and total) of social forms and bonds as well as modes of government. Stability is only ever temporary, and there is no progression in either social or personal senses. Social and personal progress is undone continually by inhuman acts of violence, carried out by zombies.

The Walking Dead is an extended meditation on the reconstitution of community life under conditions of social collapse. Creator Kirkman explicitly suggests as much 
when he asks readers to consider how they would survive in a world without the infrastructure of modern consumer capitalism, and what sort of people they would become when confronted by a daily struggle over the necessities of life (Kirkman \& Moore 2008). Survival, and not a project of political renewal, is the objective of The Walking Dead. As such it offers a fictional meditation on the political conditions of the Anthropocene as a ruined earth.

The location of The Walking Dead within the southern states of the USA is suggestive of an answer to the (unasked) question 'ruined for whom?'. Gendering and racialising the Anthropocene brings forth a series of questions as to the temporality of this particular ecological catastrophe (Crist 2013; Gunaratnam and Clark 2012; Haraway 2014; Lewis and Maslin 2015). As has been noted, the long dyings and slow violence of environmental injustice have provided the context for marginal, black and poor lives for decades (Ammons and Roy 2015). Indeed, whatever 'start date' is officially chosen for the Anthropocene it will mark a legacy of expropriation, colonialism and dispossession as well as environmental injustice. The earth is already - and has long been - ruined for many.

The Anthropocene speaks to a specific ruining however: the ruining of modernity, bound to the centres of capitalist accumulation and the gendered and racialised orderings of the modern world-system. As such it speaks to not only the threat of climate change as that which undoes existing climatic (and with them biotic) regimes, but to the threats posed by the exhaustion of our current ecological regime (Moore 2015): the loss of the ecological surplus (energy, food, raw materials) that maintains the global economic system. The exhaustion of these ecological frontiers provides the material grounds for the end of human history as distinct from natural history (Chakrabarty 2009), the end of the notion of limitless socio-economic growth (Mitchell 2013), and perhaps to the very notion of progressive time as a temporality organised around the accumulation of power and knowledge (Roitman 2014). As Fortun suggests, the disasters of 'late industrialism' mark the collapse of the separations that maintain modernity (2014). Within this context our task is not to contribute to the growing body of work critiquing the concept of the Anthropocene but to begin to map out the contours of political life on a ruined earth.

Taking up the challenge of the Anthropocene as an expression of the speculative turn within geology, we turn to the imaginary presented by the first five seasons of The Walking Dead as expressive of symptoms of the emerging politics of the Anthropocene. We concentrate on the television series The Walking Dead as a fictional rendition of life on a ruined earth, an imaginary that we see as central to the project of imagining social change in the Anthropocene. While we draw on the comics as additional materials, our focus is the specific imaginary of the TV series. We suggest that within this narrative political practice in the Anthropocene takes as its subject not the citizen or worker, but the survivor.

Through an exploration of The Walking Dead as an image of a ruined earth, the question of how the politics of organising human/more-than-human relations is brought into sharp relief. We contend that the Anthropocene brings the biospheric conditions of life to the forefront of political thought. This foregrounding of 'nature' does not signify a subsumption of nature into culture, nor does it denote the ascendency of humanity over nature as a masterful subject (Asafu-Adjaye et al. 2015a). Rather it suggests an unending state of vulnerability in the world, where political practice is framed as the unceasing labour of survival. Survival here is a work of care and repair, of maintaining ourselves, our social relations and our worlds against the socio-ecological unravellings of a period of complex environmental disaster.

\section{2 - The Anthropocene as a period of ruin and disaster}


Since first proposed by Crutzen et al. in 2000, the concept of the Anthropocene has been significantly developed and expanded upon, most notably by geologist Jan Zalasiewicz (2008; 2010). The concept designates a shift from the geological conditions of the past 10-12,000 years known as the Holocene to one irreversibly marked by human activity. The Anthropocene refers to the geological age defined by the aggregated species-impact of humanity - the point at which the activities of the human species became a crucially significant factor in shaping the dynamics of the Earth. It is argued that the impact of humanity is now so significant that it will be possible to be read in the geological record thousands of years from now. Humanity has altered not only the planet's ecosystems, atmosphere and surface appearance, but also it's chemistry and geology. As such, it has been argued that the 'proper' political response to the Anthropocene is to assume a stewarding role over the entirety of the earth, extending and consolidating a mastery over nature without limit (Steffen et al. 2011).

The prospect of human activity triggering irreversible change within the earth's atmosphere is the principle driving force behind the adoption of the Anthropocene as a heuristic device (Clark, 2014). Szerszynski suggests that 'the truth of the Anthropocene is less about what humanity is doing, than the traces that humanity will leave behind' (2012:169). Here we not only see the question of legacy, a question evocatively explored by Weisman in his best selling book The World without Us (2008), but, we would suggest, the question of our own extinction as a species.

To focus on our extinction is to re-centre history on humanity and in some senses void the troubles of the increasing human-non-human entanglements of the present (Latour 2004). Clark (2014) suggests that there has been an over-emphasis on the human within the Anthropocene, with a concurrent sidelining of properly geological concerns. Turning to the more-than-human world, Crist (2013) argues that the focus on human mastery as a political response to the Anthropocene works to erase the threat to the Enlightenment ideal of mastery over nature that the debasement of humanity into a mere geological force enacts. She further suggests that we undo the reversal that takes place in Anthropocenic thinking in order to lower humanity into the muck of 'merelyliving life' (2013:131) and foreground the question of limits to human mastery, focusing on what are a series of unforeseen or undesired side-effects. Recent work in science and technology studies and infrastructural studies points towards a similar conclusion (Denis, Mongili and Pontille 2015; Fortun 2014; Howe et al. 2015). Fortun suggests that it is the failures to maintain industrial infrastructure that has led to the collapse of modernist separations keeping the 'sludge' out of our lives, noting the role waste plays in producing the ruined biosphere of the Anthropocene.

Agency here, as something that denotes a specific characteristic of particular relations and qualities (Braun and Whatmore 2010; 2014a; Castree 2014b; Haraway 2014), is framed as a relationship to the on-going disasters of our epoch and the failures to maintain the socio-technical infrastructures of the Holocene. We can contrast this approach to a resurgent Prometheanism that sets out to posit the 'proper' relationship to the Anthropocene as one of renewed human mastery (or stewardship) over nature (Asafu-Adjaye et al. 2015b; Steffen et al. 2011). This latter position is, as noted by Crist, predominant within the Anthropocenic discourse of earth system scientists who often focus on the need to constitute a global human agent capable of planetary stewardship (i.e., Steffen et al. 2011).

\section{3 - The Walking Dead and Necromancy: on reading zombies}

We contend that TV shows such as The Walking Dead offer a meditation upon the idea of foregoing mastery over nature in favour of an alternate political practice. In particular, we would suggest that the show explores the labour of maintaining a form of life (Papadopoulos 2010b; Winner 1986) in a period without security on what Fortun calls "soiled ground" (2014). That is, not only a period without social or political security, but 
of a fundamental biological and geological uncertainty (Clark 2010;2014). As such the show depicts an alternative to contemporary accounts of the Anthropocene that posit a masterful human species-agency (Malm and Hornborg 2014).

The primary narration of agency vis-à-vis disaster is as a response to the breakdown of socio-technical infrastructure. Disaster is theorised to either reveal hidden social processes (Wynne 1988) or to weaken their grip (Solnit 2010) in such a way as to enable other forms of life to emerge. In both instances what enables agency to function is the disaster itself. Disaster appears as an opportunity for the work of renewal or construction. Here we find the basic engine of Modernist human history, the mechanism of crisis-renewal (Roitman 2014). Crisis reveals itself to be a problem that must be rectified or corrected for progress to be made. With the breakdown of the world, space is made for us to set to work to resolve the problems that brought about the crisis in the first place, thus enabling the accumulation of knowledge and power (ibid). Progress figures here as a kind of continual work of repair (Denis and Pontille 2015; Howe et al. 2015; Jackson 2014).

The Anthropocene as an unending disaster undoes this process of crisisrenewal. The extinctions are irreversible; the climatic and geo-chemical transformations will take thousands of years to undo, if they are undone at all (Archer 2009). The disaster is, to all intents and purposes, permanent (at least as far as humanity is concerned). Repair as a practice of renewal cannot take place. Within the Anthropocene humanity's agency is limited to the question of how to dwell within the ruins of the previous geological epoch. Neither mastery nor repair-as-renewal frame political agency. Rather, it is the question of survival that marks Anthropocenic politics out from the Modernist politics of the Holocene. Survival as a situation or mode of politics stands in contrast to calls for a renewed mastery of nature as espoused though calls for geoengineering (Hamilton 2014) or in texts such as the Ecomodernist Manifesto (AsafuAdjaye et al. 2015a).

How does survival trouble modernist distinctions between nature and culture? Survival speaks to an unsettling of the dyads upon which the discourse of the mastery of nature rests, particularly the pairing of active/passive as it maps onto culture/nature (Plumwood 1993). The vulnerability that calls for practices of survival and care on a damaged Earth is suggestive of a state of biospheric exhaustion. Agamben suggests that a condition of exhaustion enables the rethinking of ethics (2002). Extending this from the moment of exception found in the camp out to encompass the biosphere, we would argue that such a possibility extends to broader political concerns, insofar as the concept of the political still holds in such a state.

Such an ethico-political practice would contest not only the active/passive pairing, but also the notion that mastery (or survival) is ever finally achieved. Rather, a critical reading of Agamben as set out by Whyte (2013) suggests that survival is always contested within exhausted spaces, and that there is a lived contestation of the terms of survival. This is the question posed by Whyte in her reading of Giorgio Agamben's Homo Sacer, critically interrogating his notion of bare life suggesting that rather than a historical tendency towards the complete realisation of biopolitics, bare life be considered as a continually contested political terrain. We set out from Whyte's critical reading in part as an acknowledgement of the controversial nature of Agamben's bare life thesis to argue that bare survival names bare life as a contested political category.

Such a contestation could be read against the dystopian brutality of The Walking Dead as an expression of a kind of care-time (Bellacasa 2015). However, we would posit the politics of survival as found in The Walking Dead as a form of care, where not only is care 'never done' (ibid) vis-à-vis human life, but the work of caring for the conditions of life, of the worlds we precariously make and the ecologies we inhabit, is constantly at the forefront of minds, as opposed to being a 'naturalised' backdrop to the 'proper' activity of life (Bellacasa 2012; 2015; Plumwood 1993). 
The survivor, as one who cares (Bellacasa 2012; 2015; Mol 2008), offers an alternative approach to acting on the material conditions of life contrary to the renewal of a mastery over nature. With a renewal of mastery over the Earth, the planet is made once more to sink into the background, remade as an object of control and manipulation. However, what we find with survival and care is a never-ceasing emphasis on our dependency on the biosphere, and the need to continually work with its varied capacities and processes.

We are not arguing that The Walking Dead is consciously about the Anthropocene, nor suggesting the zombie itself is the political figure of the Anthropocene, as interesting as that suggestion is (Lauro and Embry 2008). Rather we understand the environment of The Walking Dead to be representative of an increasingly utilised trope in contemporary fiction; that of survival in a postcatastrophic world. Russell has noted that the core element of zombie narratives is the image of a ruined world, the old order overturned only for nothing to be posed in its place (2014:83). This contrasts with the presentation of the zombie as either the paradigmatic figure of work under neoliberalism (Shaviro 2002), the figure of postcrisis capitalism itself (Harman 2010; Quiggin 2012), or as a the hordes that necessitate a racialised security regime (Canavan 2010). We are interested in taking up Yuan's (2012) suggestion that the figure of the zombie provokes us to ask what remains of political praxis after the world has ended.

We are not interrogating The Walking Dead in search of solutions. We do not expect to find ourselves having to deal with the zombie horde and we do not necessarily think the actions taken by Rick and his cohorts are the same ones we would take in their world, let alone the ones we shall take in ours. Instead we are interested in the nature of the problematic played out through the creation and the consumption of these films and television programs. In particular we are interested in what we can take from fictional narratives of life at the end of the world in order to understand our current geological epoch.

\section{4 - The work of Surviving}

Throughout The Walking Dead's first five seasons there are sporadic echoes of the previous lives of the characters. Occasionally this serves as a dramatic device to build a sense of hope in the viewers only to then dash those hopes shortly afterwards. It is really only in the first episode of the third season that we encounter the possibility that there will be no going back to life before the collapse. While the first five seasons are dominated by a seemingly downward spiral into mere survival, there is a reoccurring tension (most strongly articulated in season six) that survival can assume a less fragile state and can become about making something more than mere survival, thus preparing the grounds for a return of some form of hope, albeit not hope for a better future, but that a particular form of life will be made to endure.

The first episode of season three opens with the characters methodically and in grim silence clearing a house first of its undead residents and then of its food, a category that also includes an unfortunate owl who has taken up residence in an attic bedroom. They arrange blankets and sleeping bags in one of the rooms and set about opening tins of dog food. Rick picks up one of the tins, and throws it away with a look that is clearly intended to show that he is experiencing a brief revisitation of the question 'what have we become?' Before the gang even have time to pluck their owl, let alone settle in for the night, an approaching zombie horde necessitates a hasty exit, travelling in salvaged vehicles not towards a final destination where a better life might unfold but simply in the direction in which the characters hope that they might find food, shelter and fuel for the next day or so. The long hair, beards, torn clothes, and general indicators of neglect 
tell us that this process has been repeated again and again since we left them at the end of season two. (The Walking Dead, Ep. 3.12012 )

Survivors exist in a world without frontiers or new territories to expand into. It is a world saturated with waste and ruins - with objects severed from their previous use values. Abandoned factories, empty buildings, quiet roads. More than this, social roles no longer hold their value. It is not who we are that forms the basis of action, but what our bodies can do. In The Walking Dead we encounter ruination and wastelands. Progressive politics ceases to work in this world as there is nothing left to transform, overturn or overthrow. There is only the question of how to survive: will it be mere survival, survival as a bare biological fact, or will it be with others, collective survival, survival as the making of a life in the ruins?

At the start of season three it appears as though even collective survival constitutes little more than bare survival with others. In season two we see Rick and his band join a farming family, creating a collective life, only for this to break down through acts of human (patriarchal) violence and the arrival of a zombie horde. The unstable settlements of the opening of season three serve to mark how time works within The Walking Dead. Rather than the time of progress that accumulates and builds (Roitman 2014), where the life takes place within an abstract space (Lefebvre 1991), what we see is time bound to the labour of survival, what Dooren calls knots of time (2014), where rather than accumulation we see a contingent process where settlements and communities are made and unmade by both human and inhuman violence. This oscillation between fragile settlement and the flight into bare survival forms the basis of the first five seasons, giving way to a more extended meditation on the forms of collective life in season six, where, following the on-going storyline of the comics, we can expect further irruptions of human and inhuman violence to undo and threaten the existences of the nascent human communities.

Reading the Anthropocene through the lens of The Walking Dead suggests that we live in an on-going complex disaster and that the terrain of struggle is no longer capitalism per-se but the inhumanity of a ruined world, of the un-natural excesses of nature (Clark 2010). This on-going disaster is significantly different to the anticipated crises of modernity and signals an end without hope of renewal or repair (Williams 2011), thus a period where works of maintenance, repair and care must be reconceived. We propose that this tension between bare survival and making a life, as an irresolvable tension, characterises politics in the Anthropocene. The question of survival as a condition of late modernity has been raised by a number of authors. Marc Abeles has suggested that survival constitutes the basic condition of political life after the decline of the welfare state (2010). This suggestion resonates with those of a number of other theorists who have suggested variously that we now dwell within an everyday atmosphere of fear (Massumi 1993; Virilio 2012), risk (Beck 1992) or 'after the future' (Berardi 2011). Abeles - like Franco Berardi - argues that the decline of the welfare state and current stuttering of neoliberal capitalism eviscerate the very notion of progress and thus the future. The Anthropocene figures a break with existing narrations of survival however, insofar as it suggests an ecological and not economic end to the future. As the name for an on-going ecological disaster that has already arrived, it is not something than can be repaired or transformed, only endured.

A sequence in the tenth episode of season five of The Walking Dead represents another point in the ongoing story where we see this seeming interminability played out. Here the situation is somewhat more dire due to an absence of residential or commercial sites from which to salvage and an absence of rain creating a serious risk of death from thirst. By this point in the story though, the reversal wherein these nomadic periods have become normality and the periods of temporary settlement have become exceptional is a well-established one. A group conversation takes place almost entirely through looks, gestures, and brief verbal exchanges ('Don't think, just eat') as the gang make their way slowly along a narrow road, occasionally veering off to investigate 
carrion or look for water. This eventually crystalises into more substantial reflection on the protagonists' condition when they take shelter in a barn.

Rick [referring to those survivors who have not yet reached adulthood]: Growing up's getting used to the world. This is easier for them

Michonne: This isn't the world...This isn't it.

Glen: It might be

Michonne: That's giving up

Rick: It's reality until we see otherwise. This is what we have to live with

(The Walking Dead, Ep. 5.10 2015)

Central to the figure of the survivor as a political agent is how time - and the future - is inhabited. In contrast to the figure of the revolutionary worker, the survivor does not overcome capitalism and begin history in a work of crisis-resolution (Roitman 2014), but instead dwells within a collapsing world. Where the worker was an agent that sought to resolve the 'final' crisis of capitalism through a dialectical movement of internal overcoming, the survivor exists within a fracturing of modernity's history. Time is no longer linear but fragmented, partial, bound to the life of the survivor. It is no longer abstract, but bound to specific activities and localities. That is to say, the survivor is not going anywhere. Nor does the survivor have a purpose beyond living unlike the revolutionary worker, be it bare life or collective life. What we see in The Walking Dead is a grappling with purposeful time without the discipline of the clock, without the 24/7 of work-time. What we see is the stumbling out of old work habits and routines into the tempos of reproductive labours shorn of their 'productive' counterparts.

In The Walking Dead we see specific tempos attached to the meeting of basic needs. There are specific tempos attached to the social life of the protagonists and the various other survivors that are encountered. All of these tempos are interspersed with inhuman zombie eruptions and novel events that set new courses and narratives in train. There is no over-riding time however. Time becomes a terrain within which to stumble and struggle. But importantly the struggle is not against anyone but our own habits; that is, with the habits of life before the catastrophe. Survival is an unending process of adaption to the world and the transformation of the self into one who can survive. Our own processes of becoming or unbecoming set the rhythm - as Rick says time and time again, 'we've all done things', and it is those 'things' that set the pace of life within the zombie-scape.

In the wastelands and ruins of The Walking Dead, time-discipline has broken down. Instead what emerges is a harsh kind of care-time (Bellacasa 2015) ${ }^{\mathrm{iii}}$, that is focused on the maintenance of bodies and social relations that does not hold to a singular tempo. Care-time is focused on living in the present in order to make it work well' (ibid). But not well - in The Walking Dead the focus is on desperately make it work at all. Or better still, it is repair-time, time focused on 'things' and their maintenance in a world that is always-already falling apart (Howe et al. 2015; Jackson 2014). The difference is perhaps that within the Anthropocene the 'ordering work' of maintenance and repair (Denis and Pontille 2015) gives way to a disorderly and disordering practice of salvage, where ruins must be further broken down if they are to be made useful once more. Here then, to dwell in a world that is always-already falling apart is, to take up Jackson's phrasing, to undertake 'broken world thinking' (ibid:222). To practice broken world thinking means to consider yourself as existing in the aftermath (ibid:237). That is, it is to posit that the disaster has already occurred and that we now dwell within it, a thesis Williams amongst others proposes as the basis for political practice today (2011).

\section{5 - Fear the living...}


Introducing the first paperback edition of the comic book version of The Walking Dead, Kirkman sets out that the comic is not a work of horror but is about 'watching Rick survive' (Kirkman \& Moore 2008). Survival in The Walking Dead is about dwelling in a ruined world littered with the dead who have become an atmosphere of inhuman violence, menacing and without end. Life within the ruins exists in a state of tension between two tendencies within survivalism: that of bare survival, the focused activities of merely fighting to survive, and that of making a life, of refusing to be reduced to bare survival and instead investing in a form of life that is at odds with the notion of unrelenting civil war that characterises bare survival (Tiqqun 2010). It is this tension that we see played out without teleology in The Walking Dead. Here we turn to the pivotal events of Season Three of the TV series to draw out this tension and its significance.

During season three Rick and the band of survivors find an apparently abandoned prison, and decide to hide out there as it is easily defended once the existing zombie population is destroyed (The Walking Dead Ep 3.12012 ). Inside the prison they encounter a small band of convicts with whom they try to negotiate a space-sharing arrangement, by putting the two groups into separate prison blocks. The deal brokered is that Rick and his group will help the convicts clear a wing of the prison that they will then live in, leaving another already cleared wing for Rick and his group. However, while clearing the new wing, the apparent leader of the convict group twice attempts to kill Rick, with Rick dispatching him to a grizzly end instead. One of the other convicts runs off to be chased by Rick, who locks him outside amidst a group of zombies (we do not see him die, but hear sounds of screaming and fighting from behind a closed door).

The episode continues, moving to a scene with the two remaining convicts, one where Rick and his group are poised to kill them, but decide to let them live in the newly cleared wing. Here we see the first act of the tension, where Rick oscillates between brutally slaying those people who appear as a threat to his group, and embracing a broader notion of life that is open to chance human encounters and new social bonds, a process often mediated through how the community of survivors is defined ('us' or 'we') (The Walking Dead Ep. 3.2 2012). These moments of The Walking Dead are always overshadowed by an atmosphere of fear born of a vulnerability of existing outside of a state of law. Will the group be betrayed? Are lives of those who are known to be 'trustworthy' being put at risk by the unknown (living) bodies? The opening up of the community of survivors suggests the need to trouble - but not eradicate - the necessarily violent work of making a world fit for some lives but not others (Dooren 2014). This moment in season three is put to the test in the next episode where the convict we thought dead, ravaged by zombies when locked outside after fleeing, returns to kill Rick. In the resulting carnage, Rick's pregnant wife Lori dies during childbirth. Rick is distraught, and descends into madness (The Walking Dead Ep. 3.16 2013).

This moment of consequence - to kill or not to kill - plays out across the season via an extended encounter with a 'gated community' ruled by a sadistic individual known as 'The Governor'. In the gated community we see a series of attempts to live life with others, letting go of the horror outside the community's walls (even if those attempts do include scenes of barbarity and zombie blood-sports). It is a contrast to the prison, which is still the scene of a life in the making, one that while safe is nothing more than a space for bare survival. Ultimately the season ends, after a series of raids, kidnappings and reprisals, in The Governor launching an assault on the prison, intending on killing Rick and his group and taking their place inside the safety of the prison walls. The assault fails and The Governor is forced to chase after his 'troops' as they flee. Once he manages to arrest their flight, he turns on his own people, killing most of them before departing with a handful of others into the ruined world (ibid). This interplay between survival and life takes place throughout the show on a series of evermore detailed levels. 
In one of the season finale's final scenes, Rick's son Carl (who is 13yrs old) shoots a boy not much older than himself, who was one of The Governors troops. The boy had surrendered, but Carl told his father that he shot the surrendering boy because 'he couldn't take the chance', telling his father that many of the group's members who had recently died, including his mother (Rick's wife Lori), had died because Rick failed to kill those responsible when he had the chance - i.e., he wasn't brutal enough. As the show progresses we see Carl become ever-more hardened to the violence of survival, at one point graphically explaining to a surviving priest in season four exactly how to make sure you kill a zombie with a machete, a process that elicits deep concern from several of the characters including Rick (ibid). This transformation, like that of his father, is not an even process implying a telos to survival. Carl - like Rick - swings between modes of survival, at turns focused on the brutality of life in the world of the walking dead, and at others on making more out of his life than mere survival. From parenthood and childhood through to love affairs, fraternal relations to friendship, the process of survival undoes them all, leaving them as a series of unresolved tensions - does one fight to survive, no matter what the cost, or is there something more to hold to, something more to live for?

Like other seasons, season three is a long exercise in brutality - in pitting the desires for community, either in a prison or in the gated community ruled by The Governor, against the savagery of a life outside the commune. The season concludes with Rick and his group victorious, but only at a high cost. The ending sees the remaining gated community survivors being bussed into the prison, to live in a now expanded community, in a moment that is expanded in the fourth season where we find a thriving community, replete with self-managed social roles, communal kitchens, makeshift schools and a farm. The prison community is ever-growing, as Rick and his band of survivors bring in more people that they find outside the walls. Rick has transformed himself - he has taken leave of the savagery of bare life and taken up farming (The Walking Dead Ep 4.12013 ).

But again the season swings between savagery and community, as The Governor returns with another band of survivors and a tank, to once again try to take the prison and enact revenge. Rick pleads with The Governor at the fence, saying that they could leave all that had happened in the past, and that they could live in the prison together. But The Governor has no faith in communal bonds - he declares Rick a liar for uttering such a thing: there is only violence and savagery, and the kind of form of life Rick is proposing is, to The Governor, nothing but a lie masking the brutality of survival. There is a battle, the prison walls are torn down, The Governor dies, zombies invade the oncerefuge, and the survivors are scattered. In a sense the story goes nowhere: there is, in the end, nowhere for it to go. There is only the pulsating narrative between bare survival and making a life, and the struggle to inhabit the process of living. (The Walking Dead Ep 4.8 2013)

\section{6 - Bare Survival}

Much has already been written on the significance of zombie narratives vis-à-vis economic crisis: from crisis of capitalism (Harman 2010) to those of the working class (Shaviro 2002). There are also numerous accounts of the effects of late Modernity as zombifying (Paik 2012) or even of the zombie as a Bartelby-esque figure of revolt (Lauro and Embry 2008). Here we want to suggest that a more provocative reading is one that takes the end of the world more seriously. After all, few economic crises actually end the world. There are however actual scientific narratives that describe the end of the world, beginning right now, or if not right now then within a few short years. And as we have noted above what defines the Anthropocene is its status as a factual description of an ending that has already arrived and manifests as an on-going disaster 
for us as a species. Indeed, as Clive Hamilton has forcefully argued the Anthropocene could signal the end of the human species (2010):

'even with the most optimistic set of assumptions... we have no chance of preventing emissions rising well above a number of critical tipping points that will spark uncontrollable climate change. The Earth's climate would enter a chaotic era lasting thousands of years before natural processes eventually establish some sort of equilibrium. Whether human beings would still be a force on the planet, or even survive, is a moot point. One thing seems certain: there will be far fewer of us.' (ibid:21-2)

The picture Hamilton paints here is one of a ruined world where humans fight to survive. If anything The Walking Dead paints a rosier picture of the future, where the only thing to be survived are zombies and brutal humans and not chaotic and monstrous weather, the inability to grow crops, rising seas and depleted resources. Reading The Walking Dead through this ecological lens suggests that the question of how we survive is central. As Paik notes, the principle ethical dilemma of The Walking Dead, and thus for the praxis of survival, is 'how far one is willing to go in order to preserve one's own life or the lives of those whom one loves' (2012:4). It is this ethical dilemma that animates the narrative oscillation in the Walking Dead between bare survival and making a life, but as an ethical dilemma it is grounded in necessity and not choice. Or rather, the choice is often posed as one over what constitutes necessity, thus making survival a contested state of life.

This dilemma could be said to speak to the tension surrounding the utilisation of 'humanity' as a universal agent within Anthropocenic discourse (Crist 2013; Haraway 2014; Todd 2015). In both instances there is a common root to the criticisms: that of the historical construction of the universal subject 'humanity'. In an effort to address this through the concept of the Anthropocene, Lewis and Maslin (2015) have suggested dating the Anthropocene from 1610, or the period of socio-demographic collapse in the Americas that followed from Spanish and Portuguese conquests. We would agree with the necessary entangling of legacies of violence and dispossession in any accounting for the emergence of the current geological epoch. But while noting this we also would suggest that the Anthropocene potentially marks a novel geo-historical terrain that must be addressed ethico-politically in its own right as the grounds of politics. That is, the planetary exhaustion of innumerable resources, the potentially catastrophic stress being placed on a number of biospheric processes, the ruination of late industrial infrastructure and the fact of climate change all suggest that the Anthropocenic earth as the terrain with and on which politics is to be made is fundamentally different to that of the Holocene. Furthermore, if as Mitchell suggests (2013) the notion of progress itself is an artefact of a particular confluence of human social organisation and energy resources, this would suggest that progress must either be radically reimagined for an earth no longer capable of sustaining boundless accumulation or give way to another political project that articulates an alternative approach to time and the more-thanhuman world.

Put simply, survival as a form of life brings out the ever-present tension between bare survival and making a life. While this tension is realised as a differentiated horizon insofar as the question of survival is organised through distinct colonial, racial, gendered and (crucially) geographical differences, differences that are radically compounded by the ecological unravelling that characterises the Anthropocene (Parenti 2011), we contend that it is nonetheless a common horizon. Or, given the Anthropocene dates a past event, a common ground. We can explore the tensions that inhere in survival as a differentiated common ground by turning to Whyte's critical reading of Agamben's notion of bare life. 
As Whyte (2013) outlines, bare life is a description of a life that has been excised from the protection of the law or community and exposed to sovereign power and the threat of death. Bare life, for Agamben, is not only a matter of exposure and expulsion. The mechanics of bare life function to divide political life from natural life (ibid:21) natural life here meaning the basic animality of life, its biological functioning, in contrast to the social forms that human life takes. Agamben does not set out to naturalise such a distinction, only to suggest that this fabricated division is fundamental to European political thought (2003). Agamben claims that the originary distinction between life and politics taints all European political traditions, rendering them all problematic as means of liberation (1998:11). This is because the expansion of the dominion of politics over life - the emergence and unfolding of biopolitics - eventually evacuates politics of substance (Agamben 2003).

As life is progressively subjected to political practice, all of life becomes managed by the logic of politics, calculable and thus stripped bare of anything particular about it. The mere fact of living, and the necessities that govern that fact, become the basis of politics and thus politics becomes biopolitics. Agamben's thought here is deeply indebted to Aristotle, in particular his distinction between life itself and the good life. Aristotle distinguishes between the biological necessities of life, necessities that push people to band together for the sake of biological life, and the good life which is a cultivation of social, ethical, artistic and political forms that can only take place once the bare necessities of life have been secured. Freedom, Aristotle believed, can only be secured once people are free from the work of survival.

Whyte's reading troubles this distinction, or at least suggests how there is no one moment survival as bare life is overcome. Rather there is a constant movement or contestation around making a life that threatens the reduction of life to bare survival. Such a reading echoes suggestions that Modernist forms of life are threatened with extinction within the Anthropocene (Hamilton 2010). Reading such suggestions critically, we could posit that the erosion of social, environmental and infrastructural security (Dalby 2009; Fortun 2014; Howe et al. 2015) produces an unstable ground of social life, threatening specific forms of life with extinction (Dooren 2014).

Returning to The Walking Dead what we see are lives that have been plunged back into the daily work of survival, the freedoms of civilised life lying in ruins. Read alongside Chakrabarty's historical theorisation that the Anthropocene marks the end of Modernist conceptions of freedom, survival, not boundless progress, becomes the ground of human sociality (2009). All of life thus appears as bare life. And yet this is not what we find detailed in The Walking Dead. Instead what we see is a process of survival that continually poses the question 'what is necessary to live?' At points in the narrative, merely living is not enough - people are willing to die for community, for friends and lovers, for transitory pleasures and for points of principle.

This question of survival vs. life is posed explicitly towards the middle of season five of the TV program. During a brief moment of respite, Rick tells the story of his grandfather who survived WWII by thinking of himself as already dead, only returning to life after the war had ended. Rick says that is how their group will survive - by imagining themselves to be 'the walking dead'. This is contested, both immediately and later on in the program by several of the characters. One character, Daryl, reacts in horror, saying that 'we ain't them, ... we ain't them'. The idea that survival is a kind of living death fills Daryl with dread. A number say that survival is not enough, and that the world is never going to recover. Speaking specifically against notions that some place clear of zombies exists, or that a cure for the catastrophe will be found, another character Glenn argues that the ruined world filled with zombies is how the future will look forever, that there is no hope of return to the past. Without the hope of return or renewal, to live as though one were dead would be to give up all hope of making a life. (The Walking Dead. Ep. 5.10. 2015) 
Contra Agamben, what is suggested by The Walking Dead is that survival is always a struggle over what will constitute a necessity, and that life cannot ever be freed from such a labour. This corresponds with Whyte's reading against Agamben, where she poses a historical sense of the politicisation of life (2013:42). Whyte suggests that at each moment we are confronted with the need to survive a question is posed: is merely surviving enough reason to live (ibid). That is, what should we consider to be the foundations of our survival, what will we count as necessities, and what forms of life we will endure. Will survival be mere survival, the reduction of politics to bare life, or will it be a new formulation, a refusal to separate how we live from what we need to live (ibid).

In The Walking Dead, this tension is never completely resolved. What we witness is a never-ceasing movement between the bare fact of survival - finding food, healing wounds, killing zombies, etc - and those moment of having a life - love, social ritual, communal and fraternal bonds, etc. What we see in The Walking Dead is a continual work of trying to find the space that can be cleared just enough to make a life and not merely fight to survive. At while there are moments of hope to be found in the narrative, what we see more often than not is the failure to make a life, perhaps best captured by the un-civilising of Rick, who becomes increasingly savage and violent as the series progress, his hopes for a life having been continually dashed and frustrated.

\section{7 - To be for some forms of life...}

As both the show and comics continue, we see ever-more collective iterations of this tension between bare survival and making a life, as both progress into narrations of a permanent state of civil war between (precariously) settled communities. In season six the TV show takes up the Alexandria plot line from the comics where Rick and his gang join a fortified township. After a series of conflicts with the township residents (and a series of deaths and violent clashes), Rick and his gang embrace the township community. This takes place for Rick after an attack by human marauders (called 'wolves') is beaten back and a zombie horde that has breached the walls of Alexandria is cleared out. The actions of the residents of Alexandria, who take up arms and destroy those bodies that threaten the community, are understood by Rick as a demonstration that they have "what it takes" to survive. Because they will fight and kill, Rick understands them to be able to be incorporated into his collective social body. They are now 'us'.

In his embrace of a broader polity, Rick does not resolve the tension between bare survival and making a life. Rather he is making the capacity for violence central to the project of making a life. Without violence, without the ability and capacity to make a space within which to live, there can be no form of life beyond bare survival.

The world of The Walking Dead is one we have suggested mirrors the ruined earth of the Anthropocene. In both it could be suggested that there is an absence of unoccupied space, an absence that manifests as an exhaustion of frontiers. The creation or reproduction of any given form of life requires putting another form of life (human or more-than-human) into question. This is not just to say that to be for some forms of life is to necessarily be against others (Dooren 2014; Winner 1986). The conflict between forms of life are intensified on a ruined earth insofar as the very possibility of accommodating conflicting or contradictory forms of life is undermined in a period without either progress or frontiers (Chakrabarty 2009; Mitchell 2013; Moore 2015). In The Walking Dead we see conflicts over both the space in which to live and the resources necessary to live. Similarly, what we are already seeing in the Anthropocene is an era of environmentally driven conflicts and the preparations of environmental states of emergency (Klare 2012; Parenti 2011). More to the point, the capacity to sustain some forms of life, particularly those consumer lifestyles of the global North, are only possible through the destruction of other spaces of human and more-than-human life. 
The Walking Dead presents us with an image of life amidst on-going ecoinfrastructural disaster - things have not been maintained, infrastructure is breaking down, and an inhuman catastrophe walks the earth consuming the unwary. The Anthropocene is as much an expression of ruined socio-technical infrastructure and its concomitant accidents in the global North as it is an expression of the impact of human socio-economic activity. The disasters of late industrialism present as complex disasters that must be endured but threaten to never be resolved. Taking care of socio-technical infrastructure in such an epoch is as much a work of salvage as it is of repair and maintenance. Salvage, as the lack of ecological surplus and of frontier space combine with the on-going disasters of the Anthropocene to produce a soiled earth that functionally undermines any capacity to lay a stable foundation for the steady reaccumulation of wealth or mastery over nature (Clark 2010; 2014; Moore 2015).

\section{8 - Salvage}

It is often the visions of looting and salvage that form the secret joy of zombie films, from the characters of Dawn of the Dead (1978) freely looting a shopping mall to the idea that everything is now up for grabs, and that you can take whatever you can claim. In The Walking Dead this joyous vision of salvage quickly gives way to a slow work of salvage that has more in common with the reproductive time of care work (Bellacasa 2015) than it does to the destruction of property-values found in other apocalyptic visions of the future.

Starting from within a period of breakdown and collapse without renewal, the continual and necessary work of repair appears as a labour of salvage, as a work of invention within the ruins (Jackson 2014). This is the second way the figure of the survivor differs from that of other modernist political agents. Where the classical vision of the worker, for example, is of one who produces value, the survivor produces nothing. The survivor salvages.

Salvage presupposes (and follows from) breakage. It is to take something that has lost its value and find a way to make it work again. In the world of The Walking Dead, everything has broken down, and everything must be salvaged - from cars, to guns, to social roles and relations, to dreams and ideas of what constitutes community and living. This is salvage in its most total and expansive mode - in a utopian mode (Williams 2011:42). See for example the transformation of the rooms, artefacts, and exercise yards of the prison in season three into the tools, equipment, and land necessary for low-key farming and treatment of the sick. Perhaps even more poignantly the reappropriation of the pipes of a church organ for the purposes of building defensive structures in the early part of season five (The Walking Dead Ep. 5.5 2014).

In The Walking Dead, capitalism as a social form has come to an end. The excesses of plague-nature have undone it. We could suggest that the Anthropocene invokes a future end of capitalism through a similar process of excessive nature storms, floods, sea-rises, etc. Or also by absences - no people, no workers, no clear ground in The Walking Dead; no oil, no soil, no room to expand in the Anthropocene. In both scenarios that which is terminated by disaster is capitalism.

This is a point that has been long made by many environmental and political thinkers, such as Richard Heinberg (2007), John Bellamy-Foster (2010), Naomi Klein (2014) and Jason Moore (2015). And despite the diversity of arguments presented by even this small sample of commentators, they all agree on two points. The first is that the cause of environmental crises is capitalism as an socio-economic system, and the second is that the endless growth required by capitalism in order to flourish not only cannot proceed indefinitely, but is in fact now at an end.

If we put political analysis and commentary to one side, we find much the same argument being increasingly made by the scientific community. From editorials in the usually-staid journal Nature calling for direct action by scientists (Grantham 2012), to 
serious sessions at major international conferences, such as that of the American Geophysical Union, where one such session was entitled 'Is Earth $F^{* *}$ ked? Dynamical Futility of Global Environmental Management and Possibilities for Sustainability via Direct Action Activism' (Mingle 2012), to the work of Dr Anderson from the Tyndall climate change research centre $(2012 ; 2013)$, there is an increasing call from within the scientific community to recognise the unviability of our current economic system.

In The Walking Dead, exchange has broken down and new uses must be found for old things. Labour is focused not on productivity but reproduction, and reproduction is not reducible to utility. As Jackson argues, when repair and not production becomes central to our understanding, economics becomes a matter of sustainability and not growth. Extending this beyond a moment of breakdown that promises a return to functionality, salvage is more of a question of making things work long enough to enable a form of life to endure. In The Walking Dead we are presented with a partial or stalled trajectory however. The struggle to salvage enough, to fabricate the space to live forms the central narrative of The Walking Dead. To be free of desperate survival, to escape from a pitiful life eating pet food, as we find the characters at the start of season three, even if all that can be found to build that freedom is a re-purposed prison, this is the tension around making a life in the ruins of the world that The Walking Dead explores (The Walking Dead Ep. 3.1. 2012). The struggle is to deepen the work of salvage and turn it into a process of invention, invention being that point where repair becomes something more, a process of 'making new' (Jackson 2014).

\section{9 - Conclusion}

The Anthropocene is an epoch marked by a pervasive ecological vulnerability, one that takes place at a planetary scale and produced by the progressive exhaustion of the environmental grounds of human social life. This is not to suggest, however, that there is a singular human subject that stands apart or indeed over a unitary 'nature'. The articulation of the concept of the Anthropocene would appear to be a political attempt by earth scientists to bring a global political subject into being (Bonneuil and Fressoz 2016), one capable of tackling 'global' issues such as climate change and biodiversity loss. Such an articulation would obscure the long history of not only environmental injustices and ecological violence (ibid), but the disaggregated character of humanity itself (Malm and Hornborg 2014), insofar as there is no singular 'human' subject. Nonetheless, the naming of the Anthropocene does mark a series of biospheric and geochemical transformations to the planet, changes that suggest a fundamental (uneven) transformation of the grounds of human life.

Contrary to attempts to renew a sense of human mastery over the earth and to subsume nature in its entirety under the rubric of human action (Crist 2013), the Anthropocene signals the deepening of the uncertainties produced by the earth sciences (Stengers 2000). Indeed, the geological science that underpins the naming of the Anthropocene undoes previous notions of terrestrial stability, (Clark 2014) and in doing so collapses human into non-human time (Chakrabarty 2009). Moreover, such an unsettling brings the more-than-human world out from the background of social life, not as an object of concern but as a locus of unpredicatable actions and events (Clark 2014). The combination of foregrounding the varied agencies of the biosphere and the production of a profound state of uncertainty and vulnerability vis-à-vis human life turns politics to questions of care, repair and reproduction (Bellacasa 2015; Jackson 2014). Or, returning to our focus on a ruined earth, to questions of survival and salvage.

We set out to explore the plausibilities of political life in the Anthropocene as an exhausted material ground of politics through a reading of The Walking Dead as an image of a ruined earth, paying particular attention to how the image of a ruined world brings the practices of organising human and more-than-human relations into sharp 
relief. The visual narrative of The Walking Dead sets out three questions relevant to the concept of the Anthropocene.

It presents viewers with an image of the lived environment as inhuman and unsettling. Infrastructure fails, social life revolves around everyday tasks and life is subject to unpredictable and frequent inhuman violence that erupts out of the refusal of the dead to die. It is not only an unpredictable world, but one that exceeds control. Rather than mastery their environments, the protagonists of The Walking Dead fight to endure within it.

The problem of endurance is a question of the character of survival. Survival is not constituted as a past event that has been overcome in order to pursue more 'properly human' tasks, in the Aristotelian sense. Nor is survival a condition to be over come; it is the character of life itself. It is a form of life in tension, where struggle is constituted as an every-present conflict to make a life and refuse the reduction of survival to bare life. Survival in this register is an acknowledgement that the inhuman and more-than-human will never return to the background, will never become something to be assumed or denied (Plumwood 1993). As such, survival is an act of unceasing reproduction - of care, maintenance and repair. The time of survival is not that of modernist notions of progress. It is not a singular historical continuum framing the accumulation of wealth, power and knowledge, but rather a complex ecology of tempos, where time is bound to specific practices, events and places. It is a kind of caretime entangled with ruined environments and infrastructures, where the narrative focus is not on making things better but making things work.

The need to focus on survival and making things work is suggestive of the inability to finally resolve the tension between bare life and making a life within survival. And as explored in the trajectories of the characters in The Walking Dead it is also suggestive of the inability to put violence into the past of social life. At no point does the violence foundational to forming social orders, from the fictional creations of community in The Walking Dead to the historical violences that mark the European legacies of colonialism and fossil fuel capitalism, ever cease. At no point does it become a matter that can be incorporated into a history of founding or forgotten within an origin story. Rather the question of violence - how violent to be, what violence is justified and what to care for or abandon - is continually posed.

Exploring the question of violence and the practice of survival through the attempts to constitute community in The Walking Dead, we have suggested that the work of the survivor in the Anthropocene be considered as a labour of salvage. As a particular mode of the practices of care and repair, salvage is grounded in what can be done with what remains. It is a practice that is limited to making do, to improvisation rather than invention.

As such, salvage sets out the limits of the politics of survival. Salvage starts with the world as it is found: it works with the ruins of the Anthropocene, the toxic drifts and broken infrastructures. The existing inequities of material wealth and distribution, the ruins of the present world, form the differentiated grounds of survival. In The Walking Dead this plays out between small bands of human survivors. In the real world we can see this difference geographically striated between those still-wealthy cities of the global North and the slums and informal settlements of the global South. In The Walking Dead the conflict over the material resources needed to make a life takes place in small armed conflicts, ambushes and fraught negotiations undertaken face to face. In the real world it is a matter of drone strikes, boarder police and military occupations (Parenti 2011).

This formulation indicates the limit of the survivor as political figure. While within the histories of working class struggles, it was always the agency of the worker that was figured to be capitalism's catastrophe (the real state of emergency), in catastrophic fantasies like The Walking Dead, the survivor changes nothing. It is catastrophe itself - the zombie plague - that appears as the historical agent. This is the 
significance of vulnerability. With the return of the inhuman as a force that shapes human social life, struggle ceases to be one for progression and instead one over the character of survival. But will survival be mere survival, the reduction of politics to bare life, or will it be a new formulation, a refusal to separate how we live from what we need to live (Whyte 2013:42). In The Walking Dead, this tension is never completely resolved. Rather it, and not progress becomes the horizon towards which the political is played out. The question raised for we who dwell within the Anthropocene is thus what kind of survival do we want, and how are we to inhabit our differentiated vulnerabilities.

\section{References}

Ables, Marc. 2010. The Politics of Survival. London: Duke University Press. Adams, Vincanne, Michelle Murphy, and Adele E Clarke. 2009. "Anticipation: Technoscience, life, affect, temporality." Subjectivity 28(1):246-65.

Agamben, Giorgio. 1998. Homo Sacer: sovereign power and bare life: Stanford University Press.

-. 2002. Remnants of Auschwitz: The Witness and the Archive. New York: Zone Books.

- 2003. The Open: Man and Animal. Stanford: Stanford University Press.

Ammons, Elizabeth, and Modhumita Roy (Eds.). 2015. Sharing the Earth: An International Environmental Justice Reader. Athens: University of Georgia Press.

Anderson, Kevin. 2012. "Climate Change going beyond dangerous - Brutal numbers and tenuous hope." Development Dialogue September 2012(What Next Volume III Climate, Development and Equity):16-40.

- 2013. "Avoiding dangerous climate change demands de-growth strategies from wealthier nations." in Kevin Anderson.

Archer, David. 2009. The Long Thaw: How humans are changing the next 100,000 years of the earth's climate. Oxford: Princeton University Press.

Asafu-Adjaye, John, Linus Blomqvist, Stewart Brand, Barry Brook, Ruth DeFries, Erle Ellis, Christopher Foreman, David Keith, Martin Lewis, Mark Lynas, Ted Nordhaus, Jr. Roger Pielke, Rachel Pritzker, Joyashree Roy, Mark Sagoff, Michael Shellenberger, Robert Stone, and Peter Teague. 2015a. "An Ecomodernist Manifesto."

-. 2015b. "An Ecomodernist Manifesto." Breakthrough Institute.

Barry, Andrew. 2013. Material Politics: Disputes Along the Pipeline. Oxford: WileyBlackwell.

Beck, Ulrich. 1992. Risk Society: Towards a New Modernity London: Sage.

Bellacasa, Maria Puig de la. 2012. "'Nothing comes without its world': thinking with care." The Sociological Review 60(2):197-216.

-. 2015. "Making time for soil: Technoscientific futurity and the pace of care." Social Studies of Science 45(5):691-716.

Bennett, Jane. 2010. Vibrant Matter: a political ecology of things. London: Duke University Press.

Berardi, Franco. 2011. After the Future. Oakland: AK Press.

Bird-Rose, Deborah. 2013. "Slowly writing into the Anthropocene." Text (20: Writing Creates Ecology and Ecology Creates Writing):1-14.

Bonneuil, Christophe, and Jean-Baptiste Fressoz. 2016. The Shock of the Anthropocene: The Earth, History and Us. London: Verso.

Braun, Bruce, and Sarah J. Whatmore (Eds.). 2010. Political Matter: Technoscience, Democracy, and Public Life. Minneapolis: University of Minnesota Press.

Buell, Lawrence. 1995. The Environmental Imagination: Thoreau, Nature Writing and the Formation of American Culture. London: Harvard University Press.

Canavan, Gerry. 2010. "'We are the walking dead: Race, time, and survival in Zombie narrative." Extrapolation 51(3):431-53. 
Canetii, Elias. 1984. Crowds and Power. New York: Farrar, Straus and Giroux.

Castree, Noel. 2014a. "Geography and the Anthropocene II: Current Contributions." Geography Compass 8(7):450-63.

-. 2014b. Making sense of nature: Representation, politics and democracy. New York: Routledge.

Chakrabarty, Dipesh. 2009. "The climate of history: Four theses." Critical Inquiry 35(2):197-222.

Clark, Nigel. 2010. Inhuman Nature: Sociable Life on a Dynamic Planet. London: Sage.

-. 2014. "Geo-politics and the disaster of the Anthropocene." The Sociological Review 62(Issue Supplement S1):19-37.

Cooper, Melinda. 2008. Life as Surplus: Biotechnology \& Capitalism in the Neoliberal Era. Seattle: University of Washington Press.

Crist, Eileen. 2013. "On the Poverty of Our Nomenclature." Environmental Humanities 3:129-47.

Dalby, Simon. 2009. Security and Environmental Change. Cambridge: Polity.

Denis, Jerome, Alessandro Mongili, and David Pontille. 2015. "Maintenance \& Repair in Science and Technology Studies." TECNOSCIENZA: Italian Journal of Science \& Technology Studies 6(2):5-15.

Denis, Jerome, and David Pontille. 2015. "Material Ordering and the Care of Things." Science, Technology, \& Human Values 40(3):338-67.

Dooren, Thom van. 2014. Flight ways: Life and loss at the edge of extinction. Columbia: Columbia University Press.

Fortun, Kim. 2014. "From Latour to late industrialism." Hau: Journal of Ethnographic Theory 4(1):309-29.

Foster, John Bellamy, Brett Clark, and Richard York. 2010. The Ecological Rift. New York: Monthly Review Press.

Grantham, Jeremy. 2012. "Be persuasive. Be brave. Be arrested (if necessary)." Nature 491(7424).

Gunaratnam, Yasmin, and Nigel Clark. 2012. "Pre-Race Post-Race: Climate Change and Planetary Humanism." Darkmatter 9(1).

Hamilton, Clive. 2010. Requiem for a species: Why we resist the truth about climate change. Sydney: Allen \& Unwin.

-. 2014. Earthmasters: The Dawn of the Age of Climate Engineering. Cornwell: Yale University Press.

Haraway, Donna J. 2014. "Anthropocene, Capitalocene, Chthulucene: Staying with the Trouble." in Arts of Living on a Damaged Planet. Santa Cruz, USA

-. 2015. "Anthropocene, Capitalocene, Plantationocene, Chthulucene: Making Kin." Environmental Humanities 6:159-65.

Harman, Chris. 2010. Zombie Capitalism: Global Crisis and the Relevance of Marx. Chicago: Haymarket Books.

Hartman, Saidiya V. 1997. Scenes of Subjection: Terror, Slavery, and Self-Making in Nineteenth-Century America. Oxford: Oxford University Press.

Heinberg, Richard. 2007. Peak Everything. Waking up in a century of decline in Earth's resources. Forest Row: Clairview Books.

Howe, Cymene, Jessica Lockrem, Hannah Appel, Edward Hackett, Dominic Boyer, Randal Hall, Matthew Schneider-Mayerson, Albert Pope, Akhil Gupta, Elizabeth Rodwell, Andrea Ballestero, Trevor Durbin, Fare`s el-Dahdah, Elizabeth Long, and Cyrus Mody. 2015. "Paradoxical Infrastructures: Ruins, Retrofit, and Risk." Science, Technology, \& Human Values:1-19.

Jackson, Steven J. 2014. "Rethinking Repair." in Media Technologies: Essays on Communication, Materiality and Society, edited by Tarleton Gillespie, Pablo Boczkowski, and Kirsten Foot. Cambridge: MIT Press.

Jensen, Derrick. 2006. Endgame: The Problem of Civilization v. 1: Seven Stories Press. 
Klare, Michael. 2012. The Race for What's Left: The Global Scramble for the World's Last Resources. New York: Metropolitan Books.

Klein, Naomi. 2014. This changes everything: Capitalism vs the climate. New York: Simon \& Schuster.

Latour, Bruno. 2004. Politics of Nature: How to Bring the Sciences into Democracy: Harvard University Press.

-. 2015. "TellingFriends from Foes in the Time of the Anthropocene." Pp. 145-55 in The Anthropocene and the Global Environment Crisis - Rethinking Modernity in a New Epoch, edited by Clive Hamilton, Christophe Bonneuil, and François Gemenne. London: Routledge.

Lauro, Sarah Juliet, and Karen Embry. 2008. "A Zombie Manifesto: The Nonhuman Condition in the Era of Advanced Capitalism." boundary 2 35(1):85-108.

Lefebvre, Henri. 1991. The Production of Space. Oxford: Blackwell Publishing.

Lewis, Simon L, and Mark A Maslin. 2015. "Defining the Anthropocene." Nature 519(7542):171-80.

Malm, Andreas, and Alf Hornborg. 2014. "The geology of mankind? A critique of the Anthropocene narrative." The Anthropocene Review 1(1):62-69.

Massumi, Brian (Ed.). 1993. The Politics of Everyday Fear. Minneapolis: University of Minnesota.

Mingle, Jonathan. 2012. "Scientists Ask Blunt Question on Everyone’s Mind." Slate Magazine.

Mitchell, Timothy. 2013. Carbon Democracy: Political Power in the Age of Oil. London: Verso.

Mol, Annemarie. 2008. The Logic of Care: Health and the Problem of Patient Choice. New York: Routledge.

Moore, Jason. 2015. Capitalism in the Web of Life: Ecology and the Accumulation of Capital. London: Verso.

Morton, Timothy. 2010. The Ecological Thought. London: Harved University Press.

Moten, Fred. 2008. "The Case of Blackness." Criticism 50(2):177-218.

Paik, Peter. 2012. "The Gnostic Zombie and the State of Nature: On Robert Kirkman's The Walking Dead." Available at SSRN: http://ssrn.com/abstract=1912203

Papadopoulos, Dimitris. 2010a. "Activist Materialism." Deleuze Studies 4(supplement):64-83.

-. 2010b. "Insurgent Posthumanism." ephemera: theory \& organisation in politics 10(2):134-51.

-. 2014. "Politics of Matter: Justice and Organisation in Technoscience." Social Epistemology: A Journal of Knowledge, Culture andPolicy 28(1):70-85.

Parenti, Christian. 2011. Tropic of Chaos. Climate Change and the New Geography of Violence. New York: Nation Books.

Plumwood, Val. 1993. Feminism and the Mastery of Nature. London: Routledge.

Quiggin, John. 2012. Zombie Economics: How Dead Ideas Still Walk among Us. Princeton: Princeton University Press.

Roitman, Janet. 2014. Anti-Crisis. London: Duke University Press.

Russell, Jamie. 2014. Book of the Dead: The Complete History of Zombie Movies. London: Titan Books.

Sexton, Jared. 2011. "The Social Life of Social Death: On Afro-Pessimism and Black Optimism." InTensions (5 (Fall/Winter 2011)):1-47.

Shaviro, Steve. 2002. "Capitalist Monsters." Historical Materialism 10(4):281-90.

Solnit, Rebecca. 2010. A Paradise Built in Hell. The Extraordinary Communities that Arise in Disaster. New York: Pengiun Books.

Star, Susan Leigh. 1999. "The Ethnography of Infrastructure." American Behavioural Scientist 43(3):377-91.

Steffen, Will, Åsa Persson, Lisa Deutsch, Jan Zalasiewicz, Mark Williams, Katherine Richardson, Carole Crumley, Paul Crutzen, Carl Folke, Line Gordon, Mario 
Molina, Veerabhadran Ramanathan, Johan Rockström, Marten Scheffer, Hans Joachim Schellnhuber, and Uno Svedin. 2011. "The Anthropocene: From Global Change to Planetary Stewardship." Ambio 40(7):739-61.

Stengers, Isabelle. 2000. The Invention of Modern Science. London: University of Minnesota Press.

Szerszynski, B. 2012. "The end of the end of nature: the Anthropocene and the fate of the human." The Oxford Literary Review 34(2):165-84.

Thrift, Nigel. 2010. "Halos: making more room in the world for new political orders." Pp. 139-76 in Political Matter: Technoscience, Democracy, and Public Life, edited by Bruce Braun and Sarah J. Whatmore. Minneapolis: University of Minnesota Press.

Tiqqun. 2010. Introduction to Civil War. Los Angeles: Semiotext(e).

Todd, Zoe. 2015. "Indigenizing the Anthropocene." Pp. 241-54 in Art in the Anthropocene: Encounters Among Aesthetics, Politics, Environments and Epistemologies, edited by Heather Davis and Etienne Turpin. London: Open Humanities Press.

Virilio, Paul. 2012. The Adminstration of Fear. Los Angeles: Semiotext(e).

Waters, Colin N, Jan Zalasiewicz, Colin Summerhayes, Anthony D Barnosky, Clément Poirier, Agnieszka Gałuszka, Alejandro Cearreta, Matt Edgeworth, Erle C Ellis, and Michael Ellis. 2016. "The Anthropocene is functionally and stratigraphically distinct from the Holocene." Science 351(6269):aad2622.

Weheliye, Alexander G. 2014. Habeas Viscus: Racializing Assemblages, Biopolitics, and Black Feminist Theories of the Human. London: Duke University Press.

Weisman, Alan. 2008. The World Without Us. Croydon: Virgin Books.

Whyte, Jessica. 2013. Castastrophe and Redemption: The Political Thought of Giorgio Agamben. New York: State University of New York Press.

Williams, Evan Calder. 2011. Combined and Uneven Apocalypse. Winchester: Zero Books.

Winner, Langdon. 1986. The Whale and the Reactor. Chicago: University of Chicago Press.

Wynne, B. 1988. "Unruly technology: practical rules, impractical discourses and public understanding'." Social Studies of Science 18(1):147-67.

Yuen, Wayne (Ed.). 2012. The Walking Dead and Philosophy: Zombie Apocalypse Now. Chicago: Open Court

Zalasiewicz, Jan, and et al. 2008. "Are we now living in the Anthropocene?" GSA Today 18(2).

Zalasiewicz, Jan, Mark Williams, Will Steffen, and Paul Crutzen. 2010. "The New World of the Anthropocene." Environment, Science \& Technology Viewpoint 44:2228-31.

Dawn of the Dead. 1978. [Film] George A. Romero. dir. USA: Laurel Group

The Walking Dead, Episode 1.1, Days Gone By. 2010. AMC. 31 October. 22.00

The Walking Dead, Episode 3.1, Seed. 2012. AMC. 14 October. 22.00

The Walking Dead, Episode 3.2, Sick. 2012. AMC. 21 October. 22.00

The Walking Dead, Episode 3.16, Welcome to the Tombs. 2012. AMC. 31 March. 22.00

The Walking Dead, Episode 4.1, 30 Days Without and Accident. 2013. AMC. 13 October. 22.00

The Walking Dead, Episode 4.8, Too Far Gone. 2013. AMC. 1 December. 22.00

The Walking Dead, Episode 5.5, Self Help. 2014. AMC. 9 November. 22.00

The Walking Dead, Episode 5.10, Them. 2015. AMC. 15 February. 22.00

i We would like to thank our fellow Historical Materialism panelists on the question of surviving the Anthropocene (2014) as well as the anonymous reviewers who offered valuable criticisms that helped us to 
strengthen this paper. Nicholas Beuret would like to thank the Fisher Center, Hobart and William Smith Colleges whose support enabled the further development of the material within this paper.

ii Of course, in line with genre conventions, the 'walkers' in Kirkman's work are never referred to as 'zombies'

iii Not that care-time in the work of Bellacasa necessarily takes up the implied positivity uncritically. Indeed, the preferred device for exploring the interrelation of care-time and soil is the practice of cultivating rot composting.

\section{Biography}

Nicholas Beuret is Research Associate at Lancaster Environmental Centre, Lancaster University. His research explores the construction of political issues through technoscience, political practice, infrastructure, policy, planning and resistance, with an emphasis on environmental problems and processes of social exclusion and abandonment.

Gareth Brown is based at the School of Business at the University of Leicester. His work focuses upon the collective political imaginaries of radical and revolutionary organisations and the methodologies via which these are developed. 